\title{
STOP 14: Morphology and internal structure of the Lāči drumlin at Tērvete village, Zemgale Drumlin Field
}

Kristaps Lamsters and Vitālijs Zelčs

University of Latvia

The Lāči drumlin is located on the western side of the Zemgale Drumlin Field. It is the highest drumlin in the environs of Tērvete (Fig. 14.1). The drumlin is $3.3 \mathrm{~km}$ long, $1.8 \mathrm{~km}$ wide and up to $18 \mathrm{~m}$ high on the stoss side, which is $67.6 \mathrm{~m}$ a.s.l. The drumlin has a rather classic shape, because it narrows and lowers in the distal direction. Its longitudinal axis strikes NNE-SSW, which corresponds to the regional ice flow direction. The internal structure of the drumlin was examined in the Lāči sand pit $\left(23^{\circ} 24^{\prime} 10^{\prime \prime} \mathrm{E}, 56^{\circ} 27^{\prime} 38^{\prime \prime} \mathrm{N}\right)$.

The glacial topography of this area formed during the initial reactivation and oscillatory retreat of the Late Weichselian Fennoscandian Ice Sheet in the North Lithuanian deglacial phase (locally termed the Linkuva phase after Meirons et al. 1976). The flow of the Zemgale ice lobe that advanced in the Central Latvian Lowland was highly divergent (Zelčs et al. 1990, 2011), as indicated by the orientation of glacial lineations (Lamsters 2012; Lamsters and Zelčs 2013). The extent of the Zemgale ice lobe during the North Lithuanian glacial phase in southcentral Latvia and north-central Lithuania is marked by the Linkuva end moraine (Āboltiņš 1970), also called the North Lithuanian marginal ridge by Karmazienè et al. (2013). The ice margin retreated from the North Lithuanian moraine position at $13.3 \pm 0.7{ }^{10} \mathrm{Be} \mathrm{ka}$ (Rinterknecht et al. 2008).

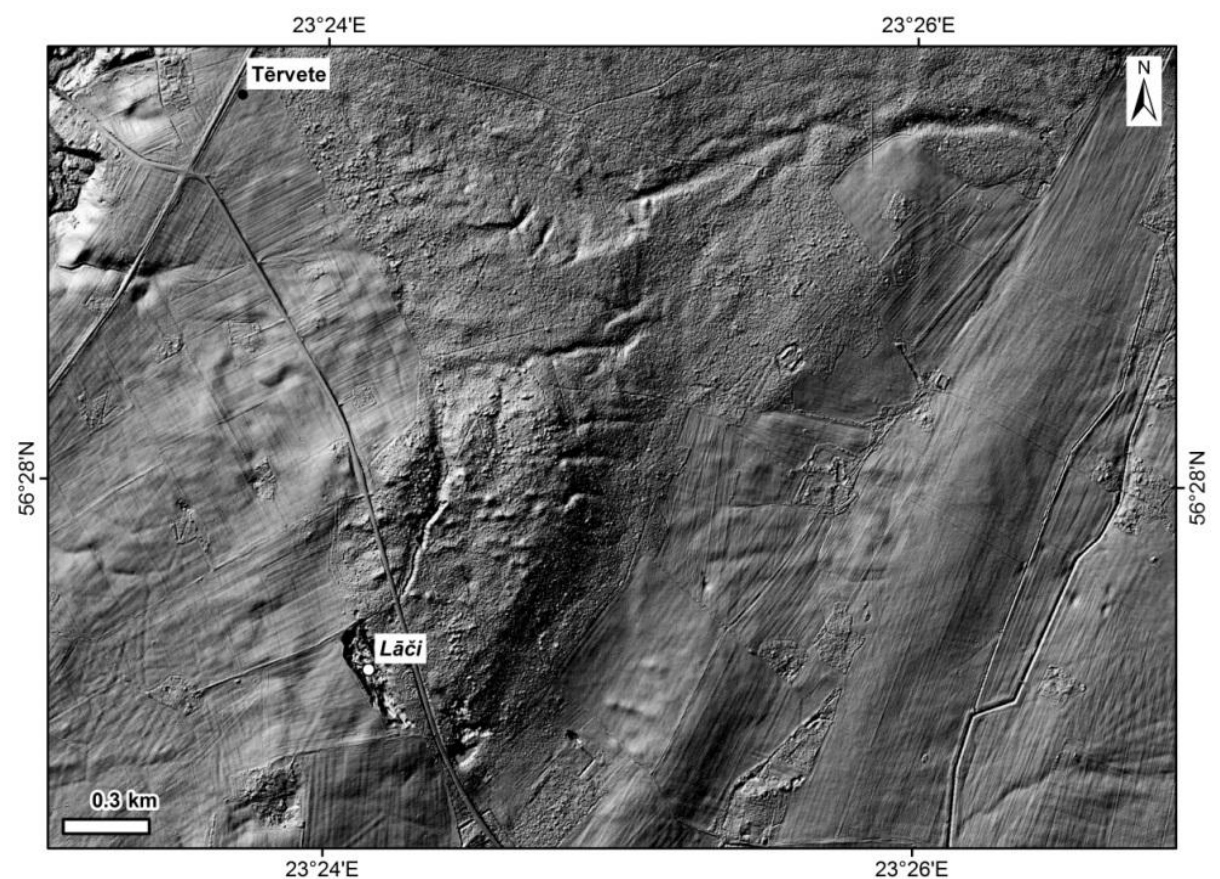

Fig. 14.1. Glacial topography in the vicinity of Tērvete, consisting of NNE-SSW striking drumlins. Note the largest drumlin and the Lāči sand pit in the lower left part of the picture. Relief-shaded DEM with grid size of 2 m. Courtesy of METRUM Ltd.

In the SW part of the Zemgale drumlin field the bedrock surface is composed of Upper Devonian Famennian sedimentary rocks. The bedrock surface increases in the direction of ice motion from $0 \mathrm{~m}$ a.s.l. in the $\mathrm{N}$ up to $70 \mathrm{~m}$ a.s.l. in the SW. The thickness of the Pleistocene, 
mainly Weichselian, deposits in this area varies from a few metres to $20 \mathrm{~m}$, although it reaches $40 \mathrm{~m}$ on the highest glacial landforms. Upglacier from the Linkuva end moraine the Pleistocene deposits consist of two till beds interbedded with sorted sediments (Dreimanis and Zelčs 1995; Zelčs and Markots 2004).

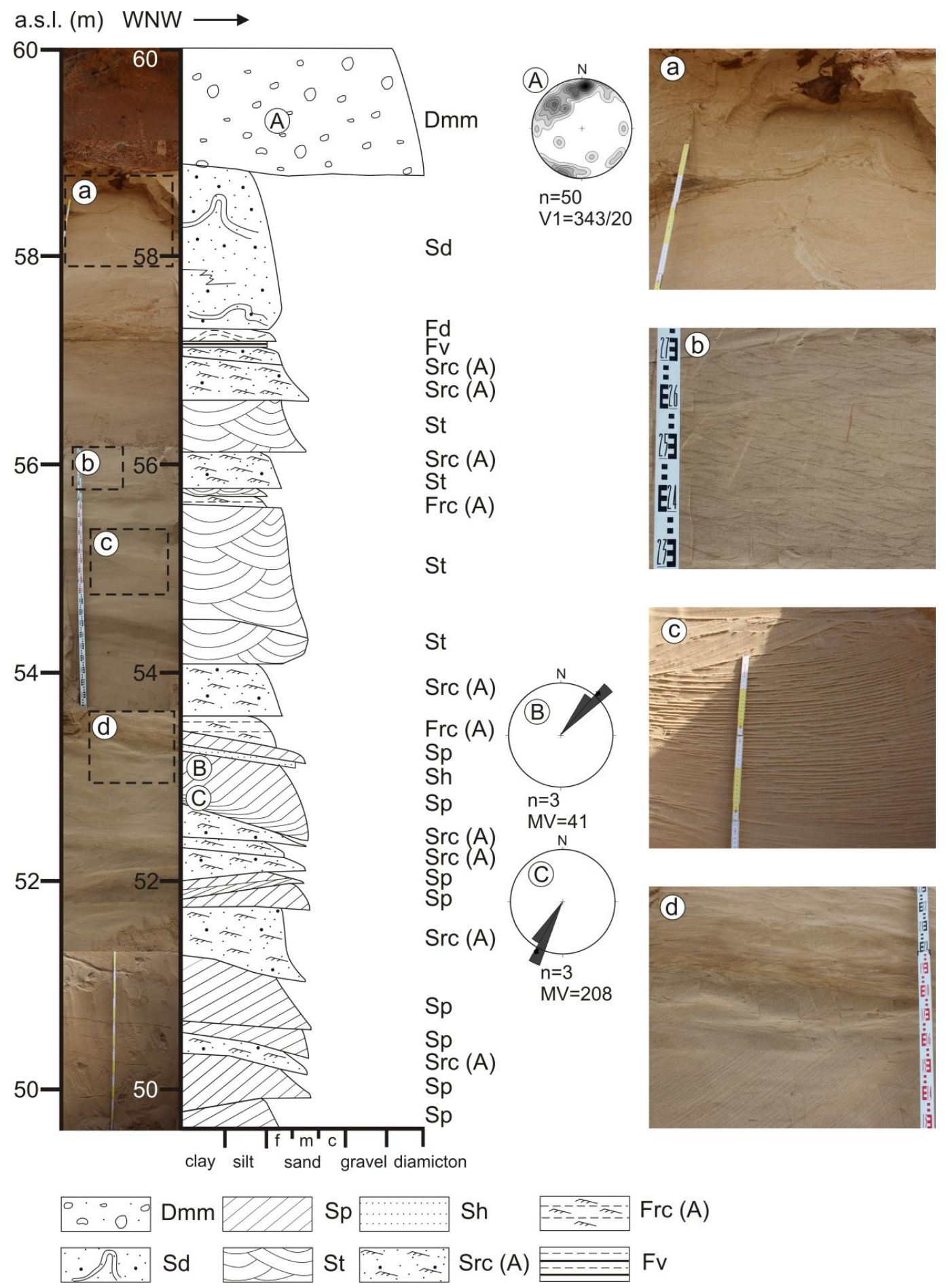

Fig. 14.2. Section at the Lāči sand pit showing glaciolacustrine sediments in the core of the drumlin. Legend: Dmm - diamicton, matrix supported, massive; Sp - planar cross-bedded sand; Sh - horizontal-laminated sand; Frc (A) - subcritically climbing-ripple cross-laminated silt; $\mathrm{Sd}$ - deformed sand; St - trough cross-bedded sand; Src (A) - subcritically climbing-ripple cross-laminated sand; Fv - parallel laminated silt, clay. Description for close-up photographs: (a) - deformed sand; (b) - sand with subcritically climbing-ripple cross-lamination; (c) trough cross-bedded sand; (d) - planar cross-bedded sand and subcritically climbing-ripple cross-laminated sandy silt in the upper part. 
The Lāči drumlin consists of stratified sediments that are capped by subglacial till a few metres thick (Figs. 14.2 and 14.3). The stratified sediments (Fig. 14.2) are composed mostly of silty to medium-grained sand that is deformed to a depth of 1-4 m. The sand is mainly planar cross-bedded, trough cross-bedded, horizontal-laminated or climbing-ripple crosslaminated.
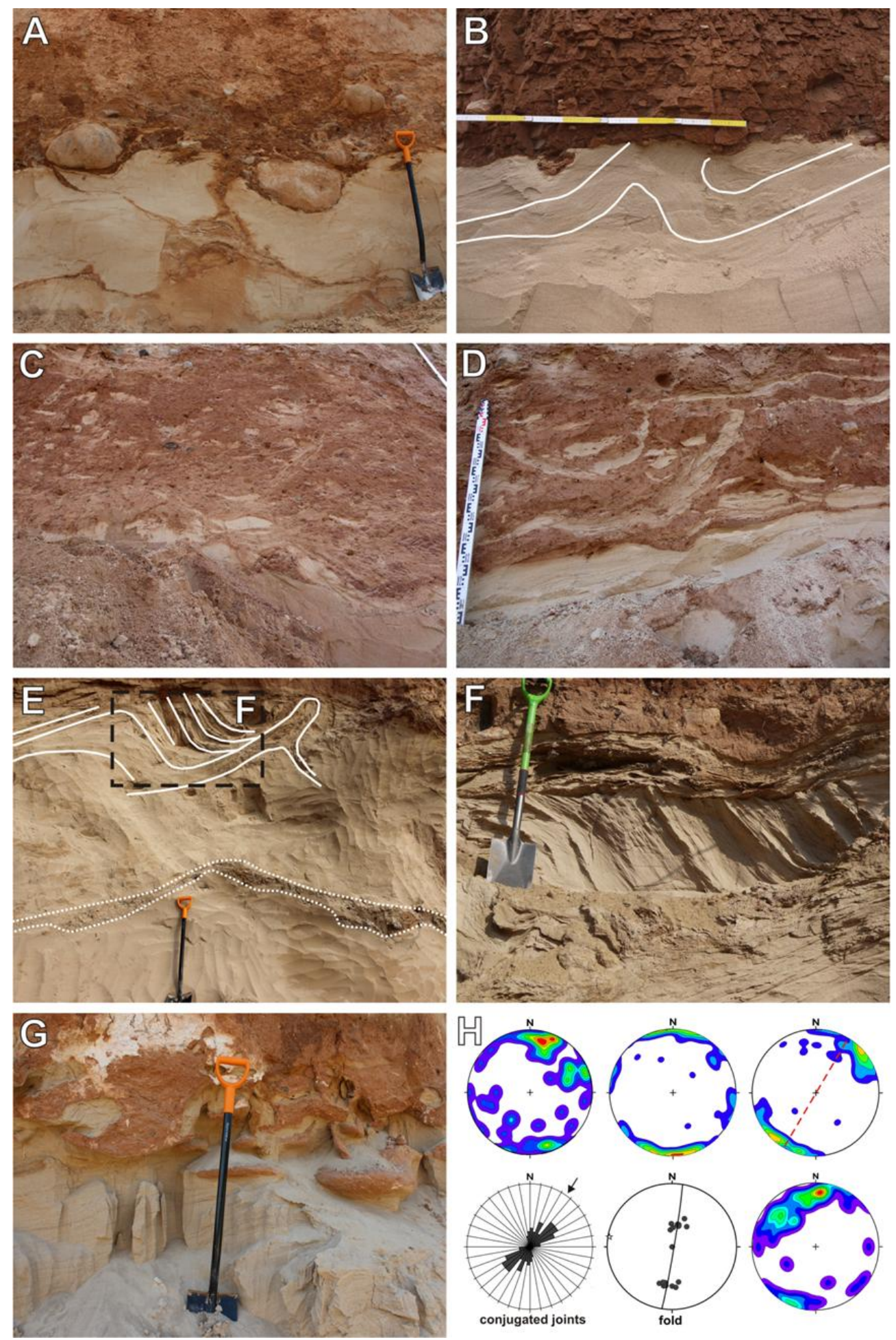

Fig. 14.3. Structures in the subglacial till forming the drumlin and underlying sandy sediments at the Laači sand pit. A. Subglacial till underlain by deformed sandy sediments. Note lodged boulders at the base of till, deformed till stringers and significant inclusion of till/silt in sandy sediments. B. Subglacial traction till with clearly visible shear planes and sub-vertical joints underlain by slightly folded fine sand. Note the almost sharp contact. C. 
Deformation till with highly attenuated and deformed sand lenses and intraclasts. Note that sand intraclasts become more deformed and rounded upwards. D. Deformation till with less attenuated, folded and boudinaged sand laminae. E. Deformed sandy sediments at a depth of at least $4 \mathrm{~m}$. Note the clearly visible asymmetrical folds just below till and deformed till lens underneath (white dotted line). F. Close-up photograph of Fig. 14.3E. Note sub-vertically bedded sand in the limb of the fold and the shear zone that cuts the upper part of the fold. G. Density driven deformation structures at the contact between till and sand. H. Stereo plots of till fabric, conjugated joints and fold structural measurements. The orientation of the drumlin crest is shown in the till fabric plot by a red line. Till fabric measurements were taken within subglacial till at different locations in the Lāči sand pit.

The prevalence of silty and fine-grained sand, less often sandy silt or even a thin clay layer, indicate glaciolacustrine sedimentation in the proximal part of a basin with high sediment supply and fluvial activity. Unfortunately, we do not know the precise time of deposition of the sediments found in the Lāči sand pit, but it is likely that they were deposited in the basin during Middle Weichselian time interval (Lejasciems interstadial in Latvia after Zelčs and Markots 2004). There are dating results from glaciolacustrine sediments on the western side of the Central Latvian lowland, giving the following OSL ages: $26.9 \pm 4.4 \mathrm{ka}$ (Hel-TL04113, Kažoki 01 site), 29.4 \pm 4.7 ka (Hel-TL04114, Kažoki 02 site) (Zelčs et al. 2011).

The ice stress direction in the drumlin was defined from measurements of the till macrofabric, constructed drag fold hinges and conjugate joints. The hinges of asymmetric folds in the sandy sediments strike perpendicular and sub-perpendicular to the crest of the drumlin (Fig. 14.3E, H). Till fabric and conjugate joints indicate ice stress variation, mostly from N-S to NE-SW (Fig. 14.3H). The determined ice stress direction is parallel or subparallel to the orientation of the longitudinal axis of the drumlin. Such fabrics, which trend approximately parallel with the drumlin crest or diverge slightly from it, have been observed frequently (Stokes et al. 2011).

Observations of the till indicate that it is likely to have been formed as subglacial lodgement till. It is characterized by well-developed fissility. Lodged clasts, faceted and striated boulders and pebbles are not uncommon. Boulders with striated lower surfaces at the base of the till present evidence that they were incorporated into the debris-rich basal part of the ice that was sliding over its bed. It is also evident from shear fractures and sand intraclasts that the till was subsequently deformed, and so could be interpreted as traction till after Evans et al. (2006). Contacts between till and underlying sand are often gradual (deformed), but erosional contacts also occur (Fig. 14.3).

It is possible to distinguish the deformation till where it is characterised by attenuated, folded and boudinaged sand laminae (Fig. 14.3D) or so-called tectonic/depositional slices of Boulton et al. (2001). In places more pervasive till deformation is common, where more attenuated sand laminas and intraclasts are visible (Fig. 14.3C). Gradual contacts and the sometimes smudgy appearance of the sand intraclasts suggest that they were incorporated into the base of the subglacial deforming layer. Strong basal ice/bed coupling and high pore-water content is also proposed; this led to the observed mixing of till and sand sediments. In places the result of this mixing is seen in the form of till blocks in a sand matrix. The possibility cannot be excluded that sandy sediments were initially frozen and that some of them remained partially frozen during deformation, because sand intraclasts are relatively well preserved in places and are not fully homogenized. In other parts observed density-driven deformation structures (dewatering) at the contact between till and sand (Fig. 14.3G) suggest high porewater content in sediments. The observed structures and contacts between till and underlying sandy sediments indicate floating pore-water pressure that resulted in episodes of ice/bed coupling and decoupling. Such conditions can best be explained by the mosaic ice-bed deformation model (Piotrowski et al. 2004), which may be applied at different scales. The 
Lāči drumlin was formed due to partial erosion/deformation of pre-existing sediments and accumulation/deformation of till.

\section{References}

Āboltinšs, O. 1970. Marginal formations of Middle Latvian tilted plain and their correlation to Linkuva (North Lithuanian) end moraine. In: Danilāns, I. (ed.), Problems of Quaternary geology, V. Zinātne, Rīga, pp. 95-107 (in Russian, with English summary).

Boulton, G.S., Dobbie, K.E. \& Zatsepin, S. 2001. Sediment deformation beneath glaciers and its coupling to the subglacial hydraulic system. Quaternary International, 86, 3-28.

Dreimanis, A., Zelčs, V. 1995. Pleistocene stratigraphy of Latvia. In: Ehlers, J., Kozarski, S., Gibbard, P. (eds.), Glacial Deposits in North-East Europe. Balkema, Rotterdam/Brookfield, pp. 105-113.

Evans, D.J.A., Phillips, E.R., Hiemstra, J.F., Auton, C.A.,2006. Subglacial till: formation, sedimentary characteristics and classification. Earth Science Reviews, 78(1-2), 115-176.

Karmazienè, D., Karmaza, B., Baltrūnas, V. 2013. Glacial geology of North Lithuanian ice marginal ridge and surrounding plains. Baltica, 26(1), 57-70.

Lamsters, K. 2012. Drumlins and related glaciogenic landforms of the Madliena Tilted Plain, Central Latvian Lowland. Bulletin of the Geological Society of Finland, 84(1), 45-57.

Lamsters, K., Zelčs, V. 2013. Glacial lineations in the Central Latvian Lowland and adjoining plains of North Lithuania. In: Satkūnas, J., Guobyte (eds), Palaeolandscapes from Saalian to Weichselian, South Eastern Lithuania. Abstracts of International Field Symposium, June 25-30, 2013, Vilnius-Trakai, Lithuania. Lithuanian Geological Survey, Vilnius, pp. 62-64.

Meirons, Z., Straume, J., Juškevics, V. 1976. Main varieties of the marginal formations and retreat of the last glaciation in the territory of Latvian SSR. In: Danilāns, I. (ed.), Problems of Quaternary Geology, 9. Zinātne, Rīga, pp. 50-73 (in Russian, with English summary).

Piotrowski, J. A., Larsen, N. K., Junge, F. W. 2004. Reflections on soft subglacial beds as a mosaic of deforming and stable spots. Quaternary Science Reviews, 23, 993-1000.

Rinterknecht, V. R., Bitinas, A., Clark, P. U., Raisbeck, G. M., Yiou, F., Brook, E. J. 2008. Timing of the last deglaciation in Lithuania. Boreas, 37(3), 426-433.

Stokes, C. R., Spagnolo, M., Clark, C. D. 2011. The composition and internal structure of drumlins: complexity, commonality, and implications for a unifying theory of their formation. Earth-Science Reviews, 107, 398422.

Zelčs, V., Markots, A., Strautnieks, I. 1990. Process formirovaniya drumlinov Sredne-Latviyskoy gliatsiodepressionnoy nizmennosti (The formation of drumlins in the Central Latvian Lowland). In: Eberhards, G., Zelčs, V., Vanaga A. (eds.), Acta Universitatis Latviensis, 547, 111-130 (in Russian).

Zelčs, V., Markots, A. 2004. Deglaciation history of Latvia. In: Ehlers, J., Gibbard, P. L. (eds.), Quaternary Glaciations - Extent and Chronology. Part I: Europe. Developments in Quaternary Science, 2. Elsevier, Amsterdam, pp. 225-243.

Zelčs, V., Markots, A., Nartišs, M., Saks, T. 2011: Chapter 18: Pleistocene Glaciations in Latvia. In: Ehlers, J., Gibbard, P.L., Hughes, P.D. (eds.), Quaternary glaciations - extent and chronology. A closer look. Developments in Quaternary Science, 15. Elsevier, pp. 221-229. 

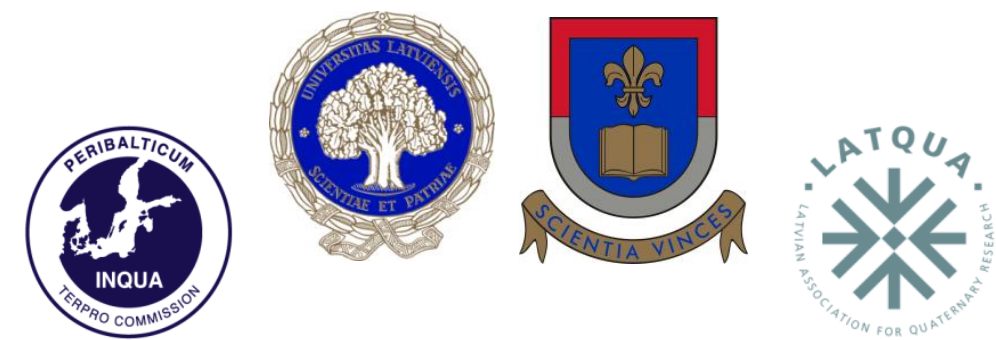

INQUA TERPRO COMMISSION PERIBALTIC WORKING GROUP

UNIVERSITY OF LATVIA

UNIVERSITY OF DAUGAVPILS

LATVIAN ASSOCIATION FOR QUATERNARY RESEARCH

\section{LATE QUATERNARY \\ TERRESTRIAL PROCESSES, SEDIMENTS AND HISTORY: FROM GLACIAL TO POSTGLACIAL ENVIRONMENTS}

EASTERN AND CENTRAL LATVIA

AUGUST 17-22, 2014 


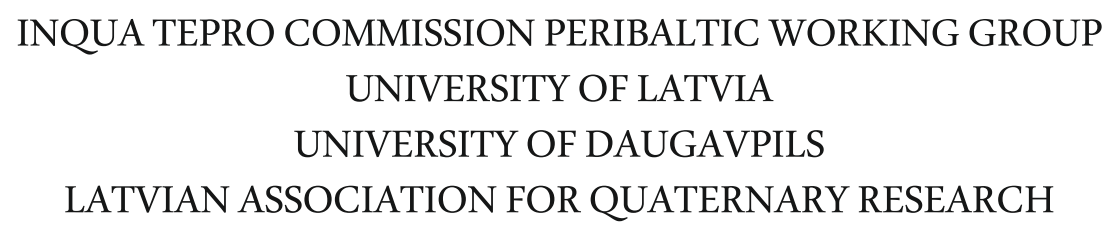

\title{
LATE QUATERNARY \\ TERRESTRIAL PROCESSES, SEDIMENTS AND HISTORY: FROM GLACIAL TO POSTGLACIAL ENVIRONMENTS
}

\author{
EASTERN AND CENTRAL LATVIA
}

AUGUST 16-22, 2014 
Organized by:

University of Latvia

Daugavpils University

Latvian Association for Quaternary Research

INQUA Peribaltic Working Group (INQUA TERPRO Commission)

Organizing committee:

Māris Nartišs (Chair, University of Latvia)

Māris Krievāns (Secretary, University of Latvia)

Aivars Markots (University of Latvia)

Juris Soms (Daugavpils University)

Evija Tērauda (University of Latvia)

Vitālijs Zelčs (University of Latvia)

Contributors:

Ivars Celiņš, Edgars Greiškalns, Ieva Grudzinska, Edyta Kalińska-Nartiša, Laimdota Kalniņa, Jānis Karušs, Māris Krievāns, Kristaps Lamsters, Aivars Markots, Māris Nartišs, Agnis Rečs, Normunds Stivriņš, Juris Soms, Ivars Strautnieks, Santa Strode, Sandra Zeimule, Vitālijs Zelčs

Editors: Vitālijs Zelčs and Māris Nartišs

The English texts of the field guide were revised by Valdis Bērziņš

Recommended reference for this publication:

Zelčs, V. and Nartišs, M. (eds.) 2014. Late Quaternary terrestrial processes, sediments and history: from glacial to postglacial environments. Excursion guide and abstracts of the INQUA Peribaltic Working Group Meeting and field excursion in Eastern and Central Latvia, August 17-22, 2014. University of Latvia, Rīga, 2014, 150 pages.

Sponsored by:

University of Latvia

Layout: Vitālijs Zelčs, Māris Nartišs and Māris Krievāns

ISBN 078-9934-517-60-0

(C) University of Latvia, 2014

This volume is available from:

Faculty of Geography and Earth Sciences

University of Latvia

Rainis Blvd. 19

Rìga, LV1586

Latvia 